\title{
INTERNALISASI NILAI PENDIDIKAN ISLAM DAN 'HABIT INFORMATION' PADA ANAK BERKEBUTUHAN KHUSUS DI TANGERANG SELATAN
}

\author{
Wari Setiawan \\ Dosen UIN Syarif Hidayatullah (DPK) pada Sekolah Tinggi Ilmu Tarbiyah \\ Islamic Village Karawaci Tangerang Selatan \\ warseserdos2014@gmail.com
}

\begin{abstract}
This paper describes an internalization in teaching and learning among a group of the disabled children in South Tangerang as a psychological process. Here, they are involved in teaching and learning activities about the Islamic values that they undertak. Meanwhile, their teachers focus on developing their personal characteristics. This paper argues that the teachers, who teach them through this process, will successfully lead them to act according to the values of Islam that the teachers convey.
\end{abstract}

Key words: disabled children (anak berkebutuhan khusus/ABK), individual learning, internalization, Islamic education (Pendidikan agama Islam/PAI).

\section{A. Pembinaan Ritual Keagamaan}

Pada Sekolah Khusus Spectrum, tujuan untuk pengembangan ritual keagamaan dicanangkan dalam kurikulumnya. Semua guru yang berada di sekolah ini berkomitmen untuk mewujudkan hal tersebut. Mereka memahami dan menyadari bahwa ABK pun memiliki hak yang sama untuk dikembangkan potensi keagamaannya. Walaupun PAI tidak ditangani khusus oleh guru PAI, namun semua guru berkomitmen untuk mewujudkannya yang dilandasi oleh kurikulum sekolah.

Personal di Sekolah Khusus Spectrum memandang bahwa sikap masyarakat memiliki nilai yang melembaga antara yang satu dengan lainnya yang berhubungan erat sehingga merupakan suatu sistem yaitu pedoman dari konsep ide dalam kebudayaan yang mendorong kuat terhadap arah kehidupan bagi seseorang. Salah satu sistem itu adalah agama.

Hal ini dikuatkan oleh teori Taufik Abdullah yang menyatakan bahwa agama merupakan refleksi atas iman yang tidak hanya merefleksikan sejauhmana kepercayaan agama diungkapkan dalam kehidupan agama, tetapi juga berhubungan dengan aspek sosial. Karena kehidupan merupakan segala 
sesuatu tindakan, perbuatan, kelakuan, yang telah menjadi kebiasaan, dan keberagamaan dapat menjadi perilaku keagamaan yang berlangsung. ${ }^{1}$

Kesadaran agama dalam pengalaman seseorang dalam hal ini, terutama pada praktik yang dijalankan oleh Sekolah Khusus Spectrum, lebih menggambarkan sisi batin dalam kehidupan yang ada kaitannya dengan sesuatu yang sakral. Dari kesadaran agama serta pengalaman keagamaan maka akan muncul sikap keberagamaan yang ditampilkan oleh seseorang. Walaupun peserta didik berbeda dengan anak normal lainnya. Hal ini dapat mendorong seseorang untuk bertingkah laku sesuai dengan kadar ketaatannya terhadap agama.

Pembinaan yang dikembangkan di Sekolah Khusus Spectrum berawal dari ritual keagamaan. Ritual dalam pandangan Koentjaraningrat merupakan tata cara dalam upacara atau suatu perbuatan keramat yang dilakukan oleh sekelompok umat beragama. Yang ditandai dengan adanya berbagai macam unsur dan komponen, yaitu adanya waktu, tempat-tempat dimana upacara dilakukan, alatalat dalam upacara, serta orang-orang yang menjalankan upacara. $^{2}$

Pada dasarnya ritual adalah rangkaian kata, tindakan pemeluk agama dengan menggunakan benda-benda, peralatan dan perlengkapan tertentu, di tempat tertentu, dan memakai pakaian tertentu pula. ${ }^{3}$ Begitu halnya dalam ritual upacara kematian, banyak perlengkapan, benda-benda yang harus dipersiapkan dan dipakai.

Ritus merupakan suatu pengungkapan terhadap simbolsimbol keyakinan beragama dalam satu sistem perilaku. Pengungkapan simbol tersebut merupakan satu bentuk ekspresi pengamalan beragama yang berisi aturanaturan pemujaan, bentuk kesucian dan sebagai salah satu sarana atau media untuk bertemu dengan yang suci. Jadi praktik ritual keagamaan adalah salah satu manifestasi dari nilai imani seseorang kepada sesuatu yang menguasai hidupnya. ${ }^{4}$

Salah satu fokus pengembangan PAI pada peserta didik adalah pembinaan ritual keagamaan. Kehidupan keagamaan peserta didik, termasuk $\mathrm{ABK}$, diharapkan dapat mengaktualisasikan ritual keagamaan berdasarkan

\footnotetext{
${ }^{1}$ Taufik Abdullah, Metodologi Penelitian Agama (Yogyakarta: PT. Tiara Wacana, 1989), 93.

${ }^{2}$ Koentjaraningrat, Beberapa Pokok Antropologi Sosial (Jakarta: Dian Rakyat, 1985), 56.

${ }^{3}$ Imam Suprayogo, Metodologi Penelitian Sosial Agama (Bandung: Remaja Rosda Karya, 2001), 41.

${ }^{4}$ Andy Dermawan, dkk. Eds, Metodologi Ilmu Dakwah (Yogyakarta: LSFI, 2002), 127.
} 
kemampuan yang dimilikinya. Proses perwujudan ritual keagamaan ini dalam konteks pendidikan menjadi hak setiap siswa ABK dengan berbagai latar belakang dan tipikalnya, yang bermuara pada pencapaian tujuan terutama bersentuhan dengan pengembangan keimanan dan ketakwaan.

Arah dan tujuan pendidikan nasional yang diwujudkan di Sekolah Khusus Spectrum seperti diamanatkan oleh UUD 1945, adalah peningkatan iman dan takwa serta pembinaan akhlak mulia para peserta didik yang dalam hal ini adalah seluruh warga negara yang mengikuti proses pendidikan di Indonesia. Oleh karena itu, pendidikan yang membangun nilai-nilai moral atau karakter di kalangan peserta didik harus selalu mendapatkan perhatian. Pendidikan di tingkat dasar (SD dan SMP) merupakan wadah yang sangat penting untuk mempersiapkan sejak dini para generasi penerus yang nantinya akan menjadi pemimpin di masa datang. ${ }^{5}$ Dalam hal ini, tak terkecuali siswa ABK.

Observasi dan wawancara di lokus penelitian Sekolah Khusus Spectrum, dapat dipahami bahwa pola pembinaan ritual keagamaan yang dilakukan di antaranya adalah:

\section{Optimalisasi Pembelajaran PAI}

Pada salah satu materi pendidikan agama, siswa berulangulang menyebutkan satu persatu, kemudian disuruh menulis. Pada siswa tunagrahita dan autis guru menghampiri satu persatu. Dalam menanamkan nilai-nilai keimanan disampaikan tentang bacaan syahadat, dibaca secara berulang-ulang secara bersama-sama.

Terkadang siswa sulit memahami hal ini. Namun yang penting siswa dapat mengucapkan dua kalimat syahadat. Guru tidak menerangkan dalil-dalil naqli karena keterbatasan kemampuan mereka. Guru di Sekolah Khusus Spectrum menuturkan bahwa meskipun para murid telah ditanya dan diberi tahu, namun 10 menit kemudian ditanya mereka tidak tahu lagi. Karena itu, untuk memudahkan pembinaan keagamaan kepada siswa maka diberi contoh yang mudah. Misalnya harus berdoa kepada Allah, artinya memohon atau meminta kepada Allah, membaca al-Hamdulillah, mentaati perintahnya seperti shalat.

\footnotetext{
${ }^{5}$ Marzuki, ,Pembinaan Karakter Siswa melalui Pendidikan Agama Islame, Jurnal Kependidikan, Vol. 41, No. 1, (Mei 2011), 45.
} 
2. Melalui Peringatan Hari Besar Keagamaan

Dari hasil wawancara dengan kepala sekolah tanggal 18 November 2016 bahwa pembinaan nilai-nilai keagamaan dilakukan pula melalui peringatan hari besar keagamaan. Salah satu yang pernah diselenggarakan misalnya Lebaran Day.

3. Pengembangan Nilai Ketaatan

Wawancara dengan guru menunjukkan bahwa usaha pembinaan nilainilai ketaatan melalui tata tertib di Sekolah Khusus Spectrum diberlakukan untuk seluruh siswa, seperti harus memakai seragam, memelihara kebersihan dan keindahan sekolah, kehadiran siswa dalam kegiatan pembelajaran. Guru berusaha untuk mensosialisasikan tata tertib sekolah dengan cara langsung mempraktekkannya, membinanya dalam kegiatan sehari-hari, bukan dengan ceramah atau hanya ditulis di papan.

Fenomena ini berhubungan dengan pembentukan manusia utuh dan berkualitas. Dalam hal PAI, yang paling utama adalah kualitas nilai agama yang bersumber dari ajaran Islam. Salah satu wahana yang paling tepat yaitu melalui upaya pembinaan nilai-nilai agama di sekolah. Sosok manusia yang baik adalah yang memiliki nilai-nilai agama Islam yang meliputi akidah ibadah dan syariah, akidah sebagai landasan pokok setiap amaliyah seorang muslim. Akidah ini meliputi semua persoalan keimanan yaitu hal-hal yang harus dipercayai dan diyakini oleh seorang muslim. Pencapaian tujuan nilainilai agama bagi ABK selain mempengaruhi kondisi diri anak juga dipengaruhi oleh masalah-masalah yang berkaitan dengan proses pembinaan anak di sekolah serta faktor ekternal lainnya seperti keluarga dan masyarakat, terutama pembinaan dari guru-guru di sekolah luar biasa. Seperti yang dikemukakan oleh Abdurrahman. ${ }^{6}$

Pada sisi lain, di Sekolah Khusus Spectrum, siswa didorong untuk menjaga kebersihan kelas. Setiap anak mendapat tugas untuk piket, kecuali yang sulit dilakukan adalah untuk anak autis. Siswa dilatih dalam membiasakan kebersihan kelas dengan cara membersihkan papan tulis, menyapu lantai dan mempersiapkan peralatan seperti spidol dan membersihkan papan tulis. Pada awalnya kegiatan ini terasa sulit bagi siswa tunagrahita dan autis, tetapi karena dibina secara terus menerus dengan penuh kesadaran yang tinggi dari guru, maka anak tunagrahita dan autis lambat laun dapat melakukan.

${ }^{6}$ Lihat Abdurrahman, Pendidikan Luar Biasa Umum (Jakarta: Dtjen Dikti, 1994), 16. 
Internalisasi Nilai Pendidikan Islam dan 'Habit Information' pada Anak Berkebutuhan Khusus di Tangerang Selatan

Pengembangan keagamaan berbasis pendidikan agama yang dikembangkan di Sekolah Khusus Spectrum berpijak pada visi dan misi yang dikembangkan oleh sekolah. Secara umum, sekolah ini mencantumkan secara langsung ataupun tidak langsung pengembangan keagamaan pada visi dan misi sekolah. Dari visi dan misi tersebut kemudian dijabarkan ke dalam berbagai program untuk menunjang keberhasilan program pendidikan keagamaan. Visi dan misi yang dikembangkan memiliki keterkaitan dengan rencana strategis yang dikembangkan. Sekolah Khusus Spectrum sebagai sekolah yang berada di bawah naungan lembaga swasta dan berciri khas untuk pendidikan $\mathrm{ABK}$ menyesuaikan dengan visi dan misi serta rencana strategis yang dikembangkan oleh lembaga terkait.

Program pengembangan keagamaan untuk ABK yang dijabarkan dari visi dan misi sekolah dimulai dengan pembuatan aturan atau tata tertib sekolah. Peraturan yang dibuat oleh sekolah menjadi acuan para siswa ABK dan warga sekolah lainnya dalam bersikap dan bertingkah laku. Pemahaman secara baik terhadap visi dan misi sekolah menjadi hal penting yang mendapat perhatian sekolah. Semua warga sekolah memahami visi dan misi yang dikembangkan sekolah. Sekolah juga dapat menerjemahkan visi dan misi tersebut ke dalam program operasional yang mudah dipahami dan dilaksanakan.

\section{Gambar 1}

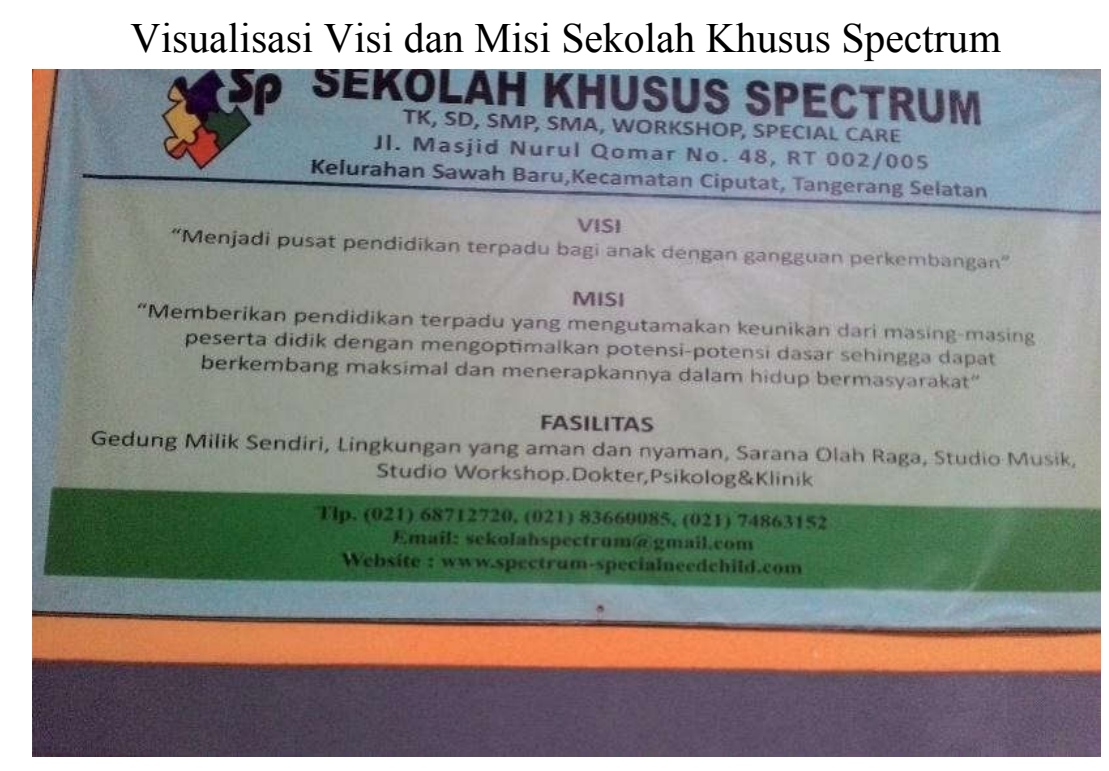

Program-program sekolah yang strategis untuk membangun karakter keagamaan telah dibuat secara rinci melalui peraturan dan tata tertib sekolah. 
Tata tertib ini menjadi dasar dan dorongan bagi para siswa dan selurus civitas sekolah dalam beraktivitas sehari-hari di sekolah. Problem yang terjadi adalah sebagian civitas sekolah baik guru, karyawan, terlebih siswa ABK terkadang tidak mengetahui dan memahami visi dan misi sekolah, sehingga arah yang ingin dicapai sekolah tidak diketahui secara pasti. ${ }^{7}$

Budaya salam, senyum, sapa, jabat tangan, dan ucapan selamat selalu diupayakan dan tidak hanya berhenti sampai batas waktu tertentu, tetapi sampai tercapai kultur akhlak mulia yang dicita-citakan sekolah. Ketercapaian budaya atau kultur akhlak mulia yang diwujudkan dalam sikap dan perilaku sehari-hari baik di sekolah maupun di luar sekolah yang disertai dengan nilainilai ibadah tidak bisa ditempuh dalam waktu yang singkat. Usaha yang telah dilakukan oleh siswa di sekolah khusus ini diupayakan untuk melakukan aktivitas inti selaku umat beragama dengan usaha konkret dalam rangka membangun karakter keagamaan melalui kegiatan-kegiatan keagamaan. ${ }^{8}$ Bersamaan dengan kegiatan-kegitan keagamaan dibudayakan juga nilai-nilai kebaikan seperti disiplin, kejujuran, rasa hormat, tanggung jawab, empati, dan nilai-nilai lainnya di sekolah. Nilai-nilai universal ini seharusnya tidak hanya dilakukan di sekolah, tetapi didorong untuk diwujudkan di mana saja dan oleh siapa saja.

Pembinaan ritual keagamaan relatif sulit dilakukan untuk anak autis. Guru tetap teguh dalam kebertahapan pembinaan ini, terutama bagi siswa muslim, berdasarkan kesepakatan dengan orangtua mereka. Nuansa pembinaan ritual tidak semarak seperti pada sekolah reguler, karena yang dihadapi adalah ABK. ${ }^{9}$ Guru lebih memperhatikan perkembangan siswa secara bertahap tidak seperti pada pencapaian anak normal. Satu gerakan shalat terkadang perlu beberapa hari diajarkan. Walaupun begitu, ada pula siswa yang cepat bisa dengan meniru gerakan gurunya.

Ritualitas keagamaan yang lancar dapat dilihat ketika siswa sudah mampu mewujudkan interaksi sosial yang lebih bagus. Seperti pelaksanaan shalat Jum'at di masjid sekitar, siswa yang dilibatkan adalah siswa yang sudah dapat bergaul dengan cukup bagus. Bagi siswa yang belum mampu menampilkan perilaku sosial yang baik, mereka tetap diajarkan di sekolah dengan optimalisasi kelas sebagai lokus binaan. ${ }^{10}$

\footnotetext{
${ }^{7}$ Hasil observasi dan wawancara pada tanggal 19 Nopember, 2016.

${ }^{8}$ Hasil observasi dan wawancara pada tanggal 19 Nopember, 2016.

${ }^{9}$ Hasil observasi dan wawancara pada tanggal 19 Nopember, 2016.

${ }^{10}$ Hasil observasi dan wawancara pada tanggal 19 Nopember, 2016.
} 
Internalisasi Nilai Pendidikan Islam dan 'Habit Information' pada Anak Berkebutuhan Khusus di Tangerang Selatan

Observasi di lapangan, terutama pada siswa autis, pembinaan ritual keagamaan relatif lebih detail, rinci, dan penuh dengan kebertahapan. Selain itu, pertimbangan psikolog sangat diperhatikan sehubungan dengan tingkat perkembangan kemampuan siswa autis. Berbeda dengan siswa ABK lainnya, mereka lebih cepat menanggapi pelaksanaan ibadah dengan peniruan gerakan dan bacaan. Hasilnya cukup berbeda dengan siswa autis. Sehubungan dengan hal ini, Kepala Sekolah, Tuharto, lebih menekankan pada pembentukan karakter sesuai dengan visi, misi, dan tujuan sekolah serta memperhatikan karakteristik dan tipikal tertentu. ${ }^{11}$

Pernyataan ini senada dengan pendapat Sardiman AM yang menjelaskan, bahwa karakter peserta didik adalah keseluruhan kelakuan dan kemampuan yang ada pada peserta didik sebagai hasil dari pembawaan dan lingkungan sosialnya. Berdasarkan pada pengertian yang dikemukakan Sardiman tersebut, dapat dipahami bahwa faktor-faktor yang mempengaruhi karakter peserta didik secara umum yaitu: faktor pembawaan dan faktor lingkungan. Kedua faktor ini yang dominan mempengaruhi karakteristik peserta didik. ${ }^{12}$

Pertama, faktor internal. Fleksibilitas (kelenturan) sifat peserta didik ditinjau dari segi fisiologi, yaitu hasil dari hakikat jaringan urat syaraf dan selsel otak. ${ }^{13}$ Syaraf dapat dipengaruhi oleh perulangan latihan yang menghasilkan adat kebiasaan sifat tertentu.

Kedua, faktor lingkungan. Lingkungan tempat peserta didik hidup diyakini besar pengaruhnya terhadap pembentukan kepribadian dan karakter peserta didik. Faktor lingkungan tersebut meliputi lingkungan keluarga, sekolah, dan masyarakat luas. Keluarga, merupakan lingkungan yang pertama dan utama dialami oleh seorang peserta didik. Situasi keluarga akan turut menentukan bagaimana karakter peserta didik dibentuk. ${ }^{14}$

Sedangkan sekolah, merupakan lingkungan tempat bertemu peserta didik dengan teman-teman yang lain. Pertemuan mereka datang dari berbagai budaya dan sosial yang berbeda-beda. Seorang peserta didik yang secara psikologis berada pada masa pencarian identitas, akan mengikuti gaya hidup temannya yang lain yang dianggapnya cocok dengan dirinya. Dengan

\footnotetext{
${ }^{11}$ Hasil wawancara dengan Tuharto pada tanggal 19 Nopember, 2016.

${ }^{12}$ Sardiman AM, Interaksi dan Motivasi Belajar Mengajar (Jakarta: Rajawali Press, 2000), 118.

${ }^{13}$ Al- Syaibani, Falafah Pendidikan Islam (Jakarta: Bintang, 1979), 159.

${ }^{14}$ Salamet, Karakter Peserta Didik dalam Perspektif Pendidikan Islame, Jurnal Pelopor Pendidikan, Vol. 3, No. 1 (Januari 2012), 33.
} 
demikian, untuk terbentuknya karakter peserta didik yang baik, Sekolah Khusus Spectrum berupaya membangun suatu lingkungan yang baik, agar peserta didik dalam menjalani hidupnya menuju pada pembinaan sifat-sifat yang positif. Walaupun pada awalnya sifat seorang peserta didik adalah baik, namun karena hidup dalam lingkungan yang tidak baik, ia dapat mengalami penyimpangan dan perubahan kepribadian sesuai dengan watak lingkungan itu sendiri.

Pembinaan keagamaan pada ABK di Sekolah Khusus Spectrum terutama untuk autis, relatif memiliki kebertahapan yang rumit dibanding dengan karakteristik lainnya. Karena mereka memiliki karakteristik autistic disorder yaitu adanya gangguan atau abnormalitas perkembangan pada interaksi sosial dan komunikasi serta ditandai dengan terbatasnya aktifitas dan ketertarikan. Munculnya gangguan ini sangat tergantung pada tahap perkembangan dan usia kronologis individu. ${ }^{15}$

Pembinaan pada siswa autis di Sekolah Khusus Spectrum di dasari pada sebuah pandangan teoritik, perilaku autistik digolongkan dalam dua jenis, yaitu perilaku yang eksesif (berlebihan) dan perilaku yang deficit (berkekurangan). Yang termasuk perilaku eksesif adalah hiperaktif dan tantrum (mengamuk) berupa menjerit, menggigit, mencakar, memukul, dan sebagainya. Di sini juga sering terjadi anak menyakiti dirinya sendiri (selfabused). Perilaku deficit ditandai dengan gangguan bicara, perilaku sosial kurang sesuai, defisit sensori sehingga dikira tuli, bermain tidak benar dan emosi yang tidak tepat, misalnya tertawa-tawa tanpa sebab, menangis tanpa seba, dan melamun. ${ }^{16}$

World Health Organization's International Classification of Diseases (ICD-10) mendefinisikan autisme (dalam hal ini khusus childhood autism) sebagai adanya keabnormalan dan atau gangguan perkembangan yang muncul sebelum usia tiga tahun dengan tipe karakteristik tidak normalnya tiga bidang yaitu interaksi sosial, komunikasi, dan perilaku yang diulang-ulang. ${ }^{17} \mathrm{WHO}$ juga mengklasifikasikan autisme sebagai gangguan perkembangan sebagai hasil dari gangguan pada system syaraf pusat manusia.

\footnotetext{
${ }^{15}$ Lihat American Psychiatric Association, Diagnostic and Statistical Manual of Mental Disorder (Washington DC: APA, 2000), 92.

${ }^{16}$ American Psychiatric Association, Diagnostic and Statistical Manual of Mental Disorder (Washington DC: APA, 2000), 93.

${ }^{17}$ World Health Organization, The ICD-10 Classification of Mental and Behavioral Disorder (Genewa: WHO, 1992), 232.
} 
Internalisasi Nilai Pendidikan Islam dan 'Habit Information' pada Anak Berkebutuhan Khusus di Tangerang Selatan

Autisme dimulai pada awal masa kanak-kanak dan dapat diketahui pada minggu pertama kehidupan. Dapat ditemukan pada semua kelas sosial ekonomi maupun pada semua etnis dan ras. Penderita autisme sejak awal kehidupan tidak berhubungan dengan orang lain dengan cara yang biasa. Sangat terbatas pada kemampuan bahasa dan sangat terobsesi agar segala sesuatu tetap pada keadaan semula (sama).

Delapan puluh persen anak autis memiliki IQ dibawah 70 yang bisa digolongkan juga sebagai retardasi mental. Akan tetapi autisme berbeda dengan retardasi mental. Penderita retardasi mental menunjukkan hasil yang memprihatinkan pada semua bagian dari sebuah tes inteligensi. Berbeda dengan penderita autis, mereka mungkin menunjukkan hasil yang buruk pada hal yang berhubungan dengan bahasa tetapi mereka ada yang menunjukkan hasil yang baik pada kemampuan visual-spatial, perkalian empat digit, atau memiliki long term memory yang baik. Mereka mungkin memiliki bakat besar yang tersembunyi. ${ }^{18}$

Penderita autism yang ada di Sekolah Khusus Spectrum secara umum mengalami tiga jenis kesulitan, yang sering disebut the triad of impairments, yaitu:

1. Interaksi sosial (kesulitan dalam menjalin hubungan sosial, contohnya menjauh atau bersikap dingin dan tidak menghiraukan orang lain).

2. Komunikasi sosial (kesulitan dalam komunikasi baik verbal maupun nonverbal, contohnya tidak mengerti arti dari isyarat yang umum, ekspresi wajah, dan nada suara), dan.

3. Imajinasi sosial (kesulitan dalam mengembangkan permainan interpersonal dan imajinasi, sebagai contoh mempunyai hanya sedikit aktifitas imajinatif, meniru, dan hanya mengulang-ulang).

\section{B. Pendidikan Agama Islam dan Keteladanan}

Pembelajaran PAI dapat terlaksana dengan baik, salah satunya dipengaruhi oleh faktor keteladanan guru. Pada dasarnya perubahan perilaku yang dapat ditunjukan oleh peserta didik harus dipengaruhi oleh latar belakang pendidikan dan pengalaman yang dimiliki oleh seorang guru. Atau dengan perkataan lain, guru mempunyai pengaruh terhadap perubahan perilaku peserta didik. Untuk itulah guru harus dapat menjadi contoh (suri teladan) bagi peserta didik, karena pada dasarnya guru adalah representasi dari sekelompok

\footnotetext{
${ }^{18}$ Gerald C. Davison, Abnormal Psychology (New York: John Wiley and Sons, 1998), 436-437.
} 
orang pada suatu komunitas atau masyarakat yang diharapkan dapat menjadi teladan, yang dapat digugu dan ditiru.

Keteladanan ini sangat bersentuhan dengan tujuan utama dari pendidikan Islam yaitu pembentukan akhlak dan budi pekerti yang sanggup menghasilkan orang-orang yang bermoral, laki-laki maupun perempuan, jiwa yang bersih, kemauan yang keras, cita-cita yang benar dan akhlak yang tinggi, tahu arti kewajiban dan pelaksanaannya, dan menghormati hak asasi manusia. Selain itu, sisa dapat membedakan baik dan buruk, memilih suatu fadilah karena ia cinta pada fadilah, menghindari suatu perbuatan yang tercela, karena ia tercela, dan mengingat Tuhan dalam setiap pekerjaan yang mereka lakukan. ${ }^{19}$

Keteladanan berasal dari kata teladan yang menurut KBBI (Kamus Besar Bahasa Indonesia) bermakna ,sesuatu yang patut ditiru atau baik untuk dicontoh ${ }^{\circ}$. Dengan demikian, keteladanan berarti hal yang dapat ditiru atau dicontoh. ${ }^{20}$ Keteladanan adalah cara memimpin yang paling efektif. Metode membimbing yang paling tidak diragukan lagi kekuatannya. Allah meminta umat Islam agar meneladani perilaku Rasulullah Saw. (QS al-Ahzab: 21).

Perintah al-Qur'an ini secara tersirat dapat juga dimaknai bahwa pendidikan yang baik dan efektif adalah dengan cara memberi keteladanan, bukan hanya perkataan. Kalau keteladanan mutlak diperlukan dalam memimpin dan mendidik orang dewasa, maka ia semakin mutlak diperlukan sebagai metode dalam mendidik dan menuntun anak ke arah kebaikan yang kita inginkan. Metode keteladanan memiliki peranan penting dalam membentuk pribadi manusia, sebab jika keteladanan seorang bapak akan membuat positif bagi pendidikan, jika ia buruk maka akan memiliki hasil negatif bagi pendidikan. ${ }^{21}$

Sekolah Khusus Spectrum memberikan perhatian pada aspek keteladanan, terutama pada seluruh guru yang mengajar. Pada situasi sosial, guru lebih dahulu mengucapkan salam dengan senyuman dengan siswanya, datang lebih dulu, dan menjadi pionir dalam setiap kegiatan yang mengarah pada pembentukan karakter keagamaan. Hal ini, tidak hanya dilakukan oleh

\footnotetext{
${ }^{19}$ Muhamad Athiyah Al-Abrasy, Dasar-Dasar Pokok Pendidikan Islam, Terj. Bustomi A. Ghoni dan Jauhar Bahri (Jakarta: Bulan Bintang, 1970), 108.

${ }^{20}$ Tim Penyusun, Kamus Besar Bahasa Indonesia (Jakarta: Balai Pustaka, 1999), 321.

${ }^{21}$ Mudzakir Ali, Ilmu Pendidikan Islam (Semarang: PKPI 2 Universitas Wahid Hasyim, 2009), 148.
} 
Internalisasi Nilai Pendidikan Islam dan 'Habit Information' pada Anak Berkebutuhan Khusus di Tangerang Selatan

guru, tapi oleh semua warga sekolah yang menerapkan prinsip sekolah ramah dengan menghargai setiap potensi siswa ABK.

Pendidikan Agama Islam dengan keteladaan ini dikembangkan memperhatikan nilai-nilai Islam yang mengedepankan prinsip-prinsip Islam yang humanis, toleran, demokratis, dan multikultural. Islam yang humanis dalam konteks Sekolah Khusus Spectrum, memandang kesatuan manusia sebagai makhluk ciptaan Allah, memiliki asal-usul yang sama, menghidupkan rasa perikemanusiaan, dan mencita-citakan pergaulan hidup yang lebih baik. Nilai-nilai Islam humanis yang dapat diimplementasikan dalam kehidupan sehari-hari bagi peserta didik di antaranya adalah: rendah hati, hidup sederhana, beramal salih, jujur, dan menepati janji. ${ }^{22}$

Sekolah Khusus Spectrum mengembangkan prinsip Islam yang toleran. Hal ini diwujudkan melalui sikap menghargai pendapat, pandangan, kepercayaan, atau kebiasaan yang berbeda dengan pendirian seseorang, juga tidak memaksa, tetap berlaku baik, lemah lembut, dan saling memaafkan. Demokratis yang dikembangkan memiliki arti mengutamakan persamaan hak dan kewajiban serta perlakuan yang sama bagi sesama dengan mengutamakan kebebasan berekspresi, berkumpul, dan mengemukakan pendapat sesuai dengan norma dan hukum yang berlaku. Multikultural berarti bersikap mengakui, akomodatif, dan menghormati perbedaan dan keragamaan budaya, untuk mencari dan memudahkan hubungan sosial, serta gotong royong demi mencapai kebaikan bersama. Nilai-nilai multikultural dalam Islam yang dapat diimplementasikan dalam kehidupan sehari-hari bagi peserta didik di antaranya adalah gemar menolong. ${ }^{23}$

Beberapa temuan di lokasi penelitian, terdapat perencanaan program pendidikan keagamaan dalam bingkai pendidikan karakter yang berawal dari visi, misi, dan tujuan yang hendak dicapai oleh sekolah. Untuk membuat sebuah perencanaan program pendidikan karakter sekolah mencantumkan secara langsung mengenai karakter yang akan dikembangkan. Pada Sekolah Khusus Spectrum, terdapat beberapa hal yang diupayakan dalam membangunan perilaku keagamaan yang didorong oleh keteladanan.

1. Sekolah selalu mengusahakan dan mengembangkan perilaku organisasinya agar menjadi organisasi yang dapat membentuk perilaku

\footnotetext{
${ }^{22}$ Hasil observasi dan wawancara pada tanggal 19 Nopember, 2016.

${ }^{23}$ Hasil observasi dan wawancara pada tanggal 19 Nopember, 2016.
} 
para siswa agar menjadi orang-orang yang sukses tidak hanya mutu akademiknya tetapi sekaligus mutu nonakademiknya.

2. Sekolah merumuskan visi, misi, dan tujuan sekolah yang secara tegas menyebutkan keinginan terwujudnya karakter mulia di sekolah.

3. Pengembangan akhlak atau karakter mulia di sekolah ditunjang dengan kesadaran yang tinggi dari seluruh warga sekolah.

4. Untuk pengembangan karakter mulia, sekolah mengembangkan programprogram yang secara tegas dan rinci mendukung terwujudnya karakter atau akhlak mulia tersebut. Programprogram ini dirancang dalam rangka pengembangan atau pembiasaan siswa sehari-hari baik dalam pengamalan ajaranajaran agama maupun nilai-nilai moral dan etika universal yang dituangkan dalam peraturan sekolah.

5. Membangun karakter mulia berbasis pada pendidikan agama dilakukan dengan memaksimalkan fungsi pendidikan agama di sekolah yang tidak hanya mentranser norma agama kepada para siswa. Tetapi sampai pada pengamalan ajaran agama yang baik sehingga pada akhirnya akan terwujud pembinaan karakter mereka.

6. Terwujudnya karakter mulia di sekolah didukung dukungan sarana prasarana sekolah yang memadai. Oleh karena itu, sekolah menyediakan fasilitas yang cukup demi kelancaran pengembangan karakter mulia ini.

7. Pembinaan karakter siswa di sekolah disertai kesadaran yang tinggi dari semua komponen sekolah. ${ }^{23}$

ABK walaupun mereka merupakan anak yang memiliki karakteristik khusus, mereka tetap memerlukan pembinaan keagamaan dan keteladanan. Karena, keteladanan merupakan sebuah metode pendidikan Islam yang sangat efektif diterapkan oleh seorang guru dalam proses pendidikan. Karena pada dasarnya pendidikan merupakan usaha sadar oleh pendidik terhadap perkembangan jasmani dan rohani anak didik menuju terciptanya kepribadian yang utama. ${ }^{24}$

Dalam hal ini, prinsip-prinsip pelaksanaan metode keteladanan pada dasarnya sama dengan prinsip metode pendidikan yakni menegakkan uswah $\mathrm{h}$ \}asanah. Berkaitan dengan penerapan metode keteladanan pada Sekolah Khusus Spectrum berkaitan dengan pendapat Muhaimin dan Abdul Mujib

\footnotetext{
${ }^{23}$ Hasil observasi dan wawancara pada tanggal 19 Nopember, 2016.

${ }^{24}$ Muhammad Qutb, Sistem Pendidikan Islam, terj. Salman Harun (Bandung: PT. Al-Ma'arif, tth), 26 .
} 
Internalisasi Nilai Pendidikan Islam dan 'Habit Information' pada Anak Berkebutuhan Khusus di Tangerang Selatan

yang mengklasifikasikan prinsip penggunaan metode keteladanan sejalan dengan prinsip pendidikan Islam adalah: ${ }^{25}$

1. Memperdalam Tujuan Bukan Alat

Prinsip ini menganjurkan keteladanan sebagai tujuan bukan sebagai alat. Prinsip ini sebagai antisipasi dari berkembangnya asumsi bahwa keteladanan pendidik hanyalah sebuah teori atau konsep tetapi keteladanan merupakan tujuan. Keteladanan yang dikehendaki di sini adalah bentuk prilaku guru atau pendidik yang baik. Karena keteladanan itu ada dua yaitu keteladanan baik (uswah h \}asanah) dan keteladanan jelek (uswah sayyi'ah). Dengan melaksanakan apa yang dikatakan merupakan tujuan pendidikan keteladanan (uswah $\mathrm{h}$ \} asanah). Tujuan pendidikan Islam adalah membentuk manusia yang beriman dan bertakwa kepada Allah serta berilmu pengetahuan, maka media keteladanan merupakan alat untuk memperoleh tujuan hal tersebut. Tanpa adanya praktek dari praktisi pendidik pendidikan Islam hanyalah akan menjadi sebuah konsep belaka.

2. Memperhatikan Pembawaan dan Kecenderungan Anak Didik.

Sebuah prinsip yang sangat memperhatikan pembawaan dan kecenderungan anak didik. Dengan memperhatikan prinsip ini, seorang guru hendaknya memiliki sifat yang terpuji, pandai membimbing anak-anak, taat beragama, cerdas, dan mengerti bahwa memberikan contoh pada mereka akan mempengaruhi pembawaan dan tabiatnya. Dalam psikologi, kepentingan penggunaan keteladanan sebagai metode pendidikan didasarkan adanya insting untuk beridentifikasi dalam diri setiap manusia, yaitu dorongan untuk menjadi sama (identik) dengan tokoh yang diidolakannya.

Atas dasar karakter manusia secara fitrah mempunyai naluri untuk meiru, metode yang digunakan di Sekolah Khusus Spectrum adalah metode yang dapat disesuaikan dengan pembawaan dan kecenderungan tersebut. Implikasi dalam metode ini adalah keteladanan yang bagaimana untuk diterapkan dan disesuaikan serta diselaraskan melalui kecenderungan dan pembawaan anak tersebut.

Kenyataan ini berkaitan dengan teori al-Farabi dalam bukunya AsySyiasi seperti yang dikemukakan oleh Hery Noer Ali menyatakan bahwa anak adakalanya mempunyai bakat jelek, seperti mempunyai kecenderungan jahat

\footnotetext{
${ }^{25}$ Muhaimin, Abdul Mujib, Pemikiran Pendidikan Islam, Kajian Filosofik dan Kerangka Dasar Operasionalnya (Bandung: Trigenda Karya, 1993), 241.
} 
dan bodoh, sehingga sulit diharapkan kecerdasan dan kecakapan begitu juga ada anak yang mempunyai pembawaan luhur sehingga mudah didik. ${ }^{26}$ Dengan mengetahui watak dan kecenderungan tersebut, keteladanan di Sekolah Khusus Spectrum memberikan kontribusi pada perubahan perilaku dan kematangan pola pikir pada anak didiknya.

\section{Sesuatu yang Dapat Diindra ke Rasional}

Dalam pandangan sederhana, fenomena pembelajaran di Sekolah Khusus Spectrum berkaitan dengan pernyataan bahwa setiap manusia merasa lebih mudah memahami sesuatu yang dapat ditangkap oleh panca indranya. Dalam hal ini, Sekolah Khusus Spectrum menerapkan prinsip berangsurangsur merupakan prinsip yang sangat perlu diperhatikan untuk memilih dan mengaplikasikan sebuah metode dalam proses pendidikan. Inti pemakaian prinsip ini dalam metode keteladanan adalah pengenalan yang utuh terhadap anak didik berdasarkan umur, kepribadian, dan tingkat kemampuan mereka. Sehingga prinsip tersebut dapat menegakkan uswah hasanah (contoh tauladan yang baik) terhadap peserta didik. Prinsip yang diterapkan dari pembahasan yang indrawi menuju pembahasan yang rasional ini dalam kontek keteladanan adalah keteladanan merupakan sebuah bentuk prilaku seseorang yang dapat dilihat dan ditiru.

Bentuk aplikasi dari rasional atas keteladanan di Sekolah Khusus Spectrum adalah menciptakan sebuah prilaku yang mencerminkan nilai-nilai yang menjunjung norma agama. Dengan keteladanan dijadikan sebuah metode dalam pendidikan Islam memberi stimulus pada anak didik untuk berbuat setelah mengetahui kenyataan bahwa apa yang ajarkan dan dilakukan oleh pendidik memberikan makna yang baik dan patut contoh.

Keteladanan di Sekolah Khusus Spectrum memperhatikan situasi dan tingkat perkembangan potensi siswa ABK. Karena ABK berbeda dengan anak normal, terutama pada siswa autis dan tunagrahita, penamanan keteladanan seorang pada mereka relatif lebih susah dibandingkan dengan tipe lainnya. Dalam hal ini, keteladanan tetap dibangun dan dijunjung tinggi, walaupun prosesnya dilakukan secara bertahap. ${ }^{27}$

Walaupun siswa yang dihadapi adalah ABK, guru di Sekolah Khusus Spectrum berupaya semaksimal mungkin menjunjung tinggi keteladanan.

\footnotetext{
${ }^{26}$ Herry Noer Aly, Ilmu Pendidikan Islam (Jakarta: PT. Logos Wacana Ilmu, 1999), 180.

${ }^{27}$ Hasil observasi dan wawancara pada tanggal 19 Nopember, 2016.
} 
Internalisasi Nilai Pendidikan Islam dan 'Habit Information' pada Anak Berkebutuhan Khusus di Tangerang Selatan

Karena keteladanan dalam pendidikan merupakan metoda yang berpengaruh dan terbukti paling berhasil dalam mempersiapkan dan membentuk aspek moral, spiritual, dan etos sosial. Dalam kaitan dengan pemikiran PAI, Allah Swt juga telah mengajarkan bahwa Rasul yang diutus untuk menyampaikan risalah samawi kepada umat manusia, adalah seorang yang mempunyai sifatsifat luhur, baik spiritual, atau intelektual. Sehingga manusia belajar darinya, memenuhi panggilannya, menggunakan metodanya dalam hal kemuliaan, keutamaan dan akhlak yang terpuji. Dia mengutus Muhammad sebagai teladan yang baik bagi umat manusia di sepanjang sejara, dan bagi umat manusia di setiap saat dan tempat sebagai pelita yang menerangi dan purnama yang memberi petunjuk. ${ }^{28}$

Tentang keteladanan akhlak ini sangat penting sekali, sebab yang menjadi ruh dari pendidikan Islam adalah pendidikan akhlak. Pendidikan akhlak inilah yang paling hakiki dari pendidikan Islam. Dalam proses pendidikan, setiap pendidik di Sekolah Khusus Spectrum berusaha menjadi teladan anak didiknya. Teladan dalam semua kebaikan, bukan teladan dalam keburukan. Dengan keteladanan itu, diharapkan anak didik adakan mencontoh atau meniru segala sesuatu yang baik dalam perkataan, perbuatan pendidiknya.

Sungguh sangat mustahil bagi orangtua melarang anak. Anaknya berkata keji dan kotor, meminum-minuman keras, berjudi dan lain-lain yang jelek, bilamana si orangtua itu sendiri senang melakukannya. Demikian juga sangat sulit untuk menjadikan anak didik bertakwa dengan menyuruhnya melaksanakan shalat, berpuasa dan lain-lain jika orangtuanya/gurunya sendiri tidak melakukannya. Sebaliknya, bagi orangtua yang dalam kehidupan sehariharinya selalu menampilkan prilaku sabar, ramah, menjauhi dan melaksanakan perintah Allah, maka di dalam dirinya terdapat keteladanan.

Keteladanan dalam pendidikan adalah metoda influensif yang paling menentukan keberhasilan dalam mempersiapkan dan membentuk sifat, dan prilaku moral, spiritual dan sosial anak. Hal ini karena pendidik adalah contoh terbaik dalam pandangan anak, yang akan ditirunya dalam segala tindak tanduknya, dan sopan santunnya, disadari atau tidak bahkan jiwa dan perasaan seorang anak sering menjadi suatu gambaran pendidiknya. ${ }^{29}$

\footnotetext{
${ }^{28}$ Heris Gunawan, Filsafat Pendidikan Islam (Jakarta: Ditjen Pendidikan Islam, 2010), 285.

${ }^{29}$ Raharjo, Pemikiran Pendidikan Islam, Kajian Tokoh Klasik dan Kontemporer (Semarang: Fakultas Tarbiyah IAIN Wali Songo bekerjasama dengan Pustaka Pelajar, 1999), 66.
} 
Keberhasilan pendidikan untuk ABK sangat ditentukan pula oleh keteladanan di lingkungan rumah, dalam hal ini orangtua. Walaupun nampak belum maksimal peran orangtua dalam pendidikan ABK di rumahnya, Sekolah Khusus Spectrum menjalin kerjasama dengan mereka untuk membangun keberhasilan pendidikan.

Mereka berpandangan bahwa orangtua merupakan guru bagi anak tidak terkecuali anak berkebutuhan khusus dalam lingkungan keluarga, di mana orangtua merupakan guru yang pertama kali memberikan pendidikan, pengarahan dan lain sebagainya. Kemudian ketika orangtua mensekolahkan anak mereka yang mengalami kebutuhan khusus, maka segala sesuatu yang disampaikan oleh guru di sekolah pastinya akan ditindak lanjuti oleh para orangtua di rumah. ${ }^{30}$

Hal ini sejalan dengan pandangan Hewett dan Frenk D yang menyatakan penanganan dan pelayanan orangtua terhadap anak berkebutuhan khusus adalah sebagai berikut:

1. Sebagai pendamping utama (as aids), yaitu sebagai pendamping utama yang dalam membantu tercapainya tujuan layanan penanganan dan pendidikan anak.

2. Sebagai advokat (as advocates), yang mengerti, mengusahakan, dan menjaga hak anak dalam kesempatan mendapat layanan pendidikan sesuai dengan karakteristik khususnya.

3. Sebagai sumber (as resources), menjadi sumber data yang lengkap dan benar mengenai diri anak dalam usaha intervensi perilaku anak.

4. Sebagai guru (as teacher), berperan menjadi pendidik bagi anak dalam kehidupan sehari-hari di luar jam sekolah.

5. Sebagai diagnostisian (diagnosticians) penentu karakteristik dan jenis kebutuhan khusus dan berkemampuan melakukan treatmen, terutama di luar jam sekolah. ${ }^{31}$

Ketika potensi bakat anak berkebutuhan khusus muncul, maka pada umumnya orangtua yang pertama kali mengetahuinya. Berdasarkan pengamatan orangtua, maka segala sesuatu yang terdapat pada diri anak kemudian diinformasikan kepada guru guna dilakukan tindakan melalui program pembelajaran bagi anak berkebutuhan khusus. Melalui program pendidikan tersebut diharapakan dapat mengembangkan bakatnya.

\footnotetext{
${ }^{30}$ Hasil wawancara dengan guru Sekolah Khusus Spectrum tanggal 21 November, 2016.

${ }^{31}$ Hewett dan Frenk D, The Emotionally Child in The Classroom Disorders (USA: Ellyn and Bacon, Inc, 1968), 9.
} 
Internalisasi Nilai Pendidikan Islam dan 'Habit Information' pada Anak Berkebutuhan Khusus di Tangerang Selatan

Ketika orangtua sering melayani dan bersama dengan anak yang mengalami kebutuhan khusus, dalam hal ini orangtua akan merasakan bahwa apa yang dilakukannya adalah sesuatu yang bisa menjadi potensi bakat dalam bidang tertentu. Orangtua melakukan sharing dengan guru di sekolah agar bisa memberikan pendidikan khusus sesuai dengan bakatnya. Sehingga mampu digali dan dikembangkan bakatnya lebih dalam lagi. Sehingga dapat kesimpulan bahwa orangtua haruslah lebih berperan aktif dalam mengembangkan pendidikan dan pembelajaran anak berkebutuhan khusus. Karena orangtua adalah orang terdekat bagi anak-anaknya, sehingga mereka bisa lebih tahu dan memahami anaknya sendiri menggunakan ikatan batin atau perasan yang mereka miliki.

Bimbingan belajar dari orangtua merupakan bagian yang memiliki peran dalam membawa anak dalam mencapai tujuan yang akan diraih. Bimbingan belajar dari orangtua kepada anaknya akan membantu mengatasi kesulitankesulitan belajar yang dihadapi anak dalam proses belajarnya. Kesulitan belajar dapat disebabkan karena kemampuan belajar yang kurang memadai atau rendah, motivasi belajar yang rendah, suasana rumah yang tidak kondusif untuk belajar, hubungan antar keluarga yang kurang harmonis, keadaan ekonomi yang kurang mendukung, serta tidak adanya minat untuk belajar. Dengan kesabaran dan keuletan orangtua dalam membimbing kesulitankesulitan belajar dapat teratasi maka tujuan belajar yang berupa penguasaan keterampilan, dan pengembangan sikap dapat tercapai dengan baik.

Bimbingan belajar orangtua sangat diperlukan dalam hal penyesuaian dirinya dengan lingkungan yang mendukung proses belajar. Lingkungan terdiri dari keluarga, sekolah, dan masyarakat. Penyedian fasilitas anak merupakan sebagai bentuk dari bimbingan belajar yang dilakukan orangtua cukup berperan dalam dalam menunjang keberhasilan anak. Fasilitas belajar ini meliputi ruang belajar di upayakan senyaman mungkin agar anak merasa betah berada di ruangan tersebut. Sedangkan kelengkapan sarana belajar anak dapat diwujudkan dengan tersedianya buku penunjang pelajaran dan alat tulis yang diperlukan.

Motivasi orangtua kepada anaknya sangat penting dalam rangka meningkatkan minat dan rangsangan anak untuk belajar. Motivasi dapat diberikan melalui tiga bentuk yaitu: motivasi belajar yang bersifat tidak langsung, motivasi untuk meningkatkan dan mempertahankan prestasi, serta motivasi untuk memperbaiki prestasi. Motivasi belajar yang bersifat tidak 
langsung dapat dilakukan dengan cara memberikan semanagat kepada anak ketika anak mengalami kebosanan dalam belajar. Motivasi belajar untuk meningkatkan dan mempertahankan prestasi anak dapat dilakukan dengan cara memberikan pujian dan hadiah ketika prestasi anak meningkat. Sedangkan motivasi belajar untuk memperbaiki prestasi belajar anak dapat dilakukan dengan cara membimbing dan menasihati anak agar mau memperbaiki prestasi belajarnya.

Pemberian perhatian atau pengawasan dari orangtua kepada anaknya merupakan bagian terpenting yang harus dilakukan oleh setiap orangtua. Perhatian dan pengawasan tersebut meliputi: rutinitas kegiatan anak di rumah, pemanfaatan waktu senggang anak, kedisiplinan waktu belajar anak, gangguan atau hambatan yang dialami anak, pergaulan anak dengan temantemannya, serta prestasi belajar anak. Kurangnya perhatian dan pengawasan orangtua dapat menyebabkan anak bersikap acuh tak acuh, tidak mempunyai kemauan minat belajar. Yang akhirnya dapat menyebabkan kesulitan belajar dan tidak tercapainya prestasi belajar yang baik. Sebaliknya dengan adanya perhatian dan pengawasan dari orangtua anak akan dapat tercapai kesuksesan dalam belajar.

\section{Internalisasi Nilai Religius dalam Praktik}

Perkembangan pembelajaran pada ABK memerlukan pendekatan khusus sesuai dengan tipikal yang dimiliki. Dalam konteks pendidikan, apapun kondisi dan tipikal anak, tetap memerlukan perhatian dan dorongan untuk mengembangkan potensinya, termasuk pembentukan karakter yang di dalamnya terdapatan muatan nilai-nilai yang baik untuk kebutuhan hidupnya.

Dalam konteks PAI, nilai keimanan merupakan salah satu nilai utama yang dikembangkan di Sekolah Khusus Spectrum. Nilai ini sangat penting untuk diinternalisasikan karena nilai ini berkaitan dengan keimanan seseorang. Orang yang beriman dan bertakwa akan senantiasa menjalankan semua perintah Tuhan dan menjauhi semua larangan Tuhan karena orang yang beriman dan bertakwa mempunyai keyakinan kuat dalam dirinya bahwa setiap perbuatan pasti akan ada balasannya. Pola pikir ini menyadarkan semua guru untuk dapat menginternalisasi nilai pada siswa ABK.

Sekolah Khusus Spectrum sebagai sekolah yang menangani ABK memiliki program yang bagus untuk pengembangan karakter anak. Apapun kondisi anak, sivitas sekolah berkomitmen untuk menumbuhkembangkan 
Internalisasi Nilai Pendidikan Islam dan 'Habit Information' pada Anak Berkebutuhan Khusus di Tangerang Selatan

potensi dan karakter yang dimiilikinya dalam lingkup sosial di sekolahnya sebagai bekal kehidupan di dunia masyarakat.

Hasil wawancara dan observasi di lapangan penelitian, terdapat beberapa temuan yang berhubungan dengan internalisasi nilai di Sekolah Khusus Spectrum, yaitu:

\section{Optimalisasi Pendidikan Agama}

Siswa Muslim yang tersebar di semua kelas dan jenjang mendapatkan layanan pendidikan agama, walaupun bukan oleh guru PAI khusus, melainkan oleh guru kelas. Siswa ABK dimotivasi, dilibatkan, dan dididik untuk mempelajari dan mempraktekkan ajaran agama sesuai dengan tingkat kemampuan. Internalisasi nilai ritual dilaksanakan lebih banyak menggunakan metode imitasi, terlebih untuk siswa autis dan tunagrahita. Kompetensi menirukan, membuat kembali, menyatakan ulang lebih sering digunakan oleh guru untuk mengembangkan kompetensi yang ada pada mata pelajaran. Siswa ABK tidak terlalu ditekan untuk memahami materi secara teoritik. Pendekatan pembelajaran yang digunakan lebih mengarah pada praktik dan menggugah penghayatan nilai keagamaan, walaupun tampak belum berhasil dalam internalisasinya terutama pada siswa ABK gangguan mental.

Dalam kaitan ini, PAI baik di sekolah reguler maupun sekolah khusus, berhubungan dengan pengamalan, pengalaman, dan penghayatan keagamaan. Pada siswa ABK gangguan mental, ketiga aspek keberagamaan ini belum tampak berhasil total sesuai harapan, mengingat tipikal yang cukup kompleks. Namun, guru tetap mendorong siswa untuk dapat menginternalisasi nilai-nilai kebaikan baik bagi dirinya maupun orang lain.

\section{Pengembangan Budaya Sekolah yang Humanis}

Ketika peneliti masuk wilayah Sekolah Khusus Spectrum, terdapat sekelompok anak tunagrahita yang tersenyum dan menyapa dengan salam. Mereka tersenyum dan cukup ceria ketika melihat seseorang yang menghampiri. Fenomena ini menunjukkan terdapat item yang bersentuhan dengan keramahan di dalam lingkungan sekolah. Selain itu, slogan-slogan motivasi untuk pendidikan yang humanis tampak menghiasi dinding kelas sekolah, yang menandakan dorongan kesadaran untuk saling menghormati, menghargai, dan memahami setiap individu dengan berbagai latar belakang dan tipikal yang dimiliki, terutama terkait dengan ABK. 
Semua personal sekolah memperlakukan siswa sebagai manusia, walaupun oleh orang luar dianggap anak aneh. Siswa ABK dilayani sepenuh hati dengan berbagai pendekatan sesuai dengan tipikal yang dimiliki. Perwujudan sekolah ramah dan humanis tampak nyata dalam setiap sekuensi pembelajaran. Dalam konteks internalisasi nilai religius, guru yang ada di lingkungan Sekolah Khusus Spectrum berupaya untuk memahami bahwa ABK adalah manusia. Mereka menggunakan beberapa pendekatan dan cara seperti: ${ }^{32}$

a. Pendekatan Motivasi

Guru memberikan motivasi kepada siswa agar tetap memiliki gairah dan semangat yang tinggi dalam mengikuti kegiatan pembelajaran.

b. Memahami Konteks Siswa

Dalam hal ini, guru di Sekolah Khusus Spectrum dilatih dan dibina untuk mengenal siswa secara mendalam, menggunakan contoh dan memanfaatkan sumber belajar yang ada di lingkungan sekitar.

c. Individualisasi

Guru mengenal kemampuan awal dan karakteristik setiap anak secara mendalam baik dari segi kemampuan maupun ketidak mampuannya dalam menyerap materi pelajaran, kecepatan maupun kelambatannya dalam belajar, dan perilakunya, sehingga setiap kegiatan pembelajaran masing-masing anak mendapat perhatian dan perlakuan yang sesuai.

d. Penciptaan Hubungan Sosial

Dalam kegiatan pembelajaran, guru mengembangkan strategi pembelajaran yang mampu mengoptimalkan interaksi antara guru dengan siswa, siswa dengan siswa, guru dengan siswa dan lingkungan, serta interaksi multiarah.

e. Belajar Sambil Bekerja

Dalam kegiatan pembelajaran, guru banyak memberi kesempatan kepada anak untuk melakukan praktek atau percobaan atau menemukan sesuatu melalui pengamatan.

Siswa merupakan makhluk individu yang unik yang mana masingmasing mempunyai perbedaan yang khas, seperti perbedaan intelegensi, minat bakat, hobi, tingkah laku maupun sikap, mereka berbeda pula dalam hal latar

\footnotetext{
${ }^{32}$ Hasil oservasi pada tanggal 19 dan 20 Nopember, 2016.
}

60 | INDO-ISLAMIKA, Volume 7 No.1 Januari-Juni 2017/1438 
Internalisasi Nilai Pendidikan Islam dan 'Habit Information' pada Anak Berkebutuhan Khusus di Tangerang Selatan

belakang kebudayaan, sosial, ekonomi dan keadaan orangtuanya. Guru harus memahami perbedaan siswa secara individu, agar dapat melayani pendidikan yang sesuai dengan perbedaannya itu. ${ }^{33}$

Siswa akan berkembang sesuai dengan kemampuannya masing-masing. Setiap siswa juga memiliki tempo perkembangan sendiri-sendiri, maka guru dapat memberi pelajaran sesuai dengan temponya masing-masing. Perbedaan individual ini berpengaruh pada cara dan hasil belajar siswa. Karenanya, perbedaan individu perlu diperhatikan oleh guru dalam upaya pembelajaran.

Pendekatan pembelajaran humanistik memandang manusia sebagai subjek yang bebas merdeka untuk menentukan arah hidupnya. Manusia bertanggung jawab penuh atas hidupnya sendiri dan juga atas hidup orang lain. Pendekatan yang lebih tepat digunakan dalam pembelajaran yang humanistik adalah pendekatan dialogis, reflektif, dan ekspresif. Pendekatan dialogis mengajak peserta didik untuk berpikir bersama secara kritis dan kreatif. Pendidik tidak bertindak sebagai guru melainkan fasilitator dan partner dialog pendekatan reflektif mengajak peserta didik untuk berdialog dengan dirinya sendiri. Sedangkan pendekatan ekspresif mengajak peserta didik untuk mengekspresikan diri dengan segala potensinya (realisasi dan aktualisasi diri). Dengan demikian pendidik tidak mengambil alih tanggung jawab, melainkan sekedar membantu dan mendampingi peserta didik dalam proses perkembangan diri, penentuan sikap dan pemilahan nilai-nilai yang akan diperjuangkannya. ${ }^{34}$

Pendidikan yang humanistik menekankan bahwa pendidikan pertamatama dan yang utama adalah bagaimana menjalin komunikasi dan relasi personal antara pribadi-pribadi dan antar pribadi dan kelompok di dalam komunitas sekolah. Relasi ini berkembang dengan pesat dan menghasilkan buah-buah pendidikan jika dilandasi oleh cintakasih antar mereka. Pribadipribadi hanya berkembang secara optimal dan relatif tanpa hambatan jika berada dalam suasana yang penuh cinta (unconditional love), hati yang penuh pengertian (understanding heart) serta relasi pribadi yang efektif (personal relationship). Dalam mendidik seseorang kita hendaknya mampu menerima diri sebagaimana adanya dan kemudian mengungkapkannya secara jujur (modeling). Mendidik tidak sekedar mentransfer ilmu pengetahuan, melatih

\footnotetext{
${ }^{33}$ Skinner, B. F, Contingencies of Reinforcement (CT: Appleton, 1971), 100.

${ }^{34}$ Frank Goble, Madzhab Ketiga Psikologi Humanistik Abraham Maslow (Yogyakarta: Kanisius, 1987), 120.
} 
keterampilan verbal kepada para peserta didik, namun merupakan bantuan agar peserta didik dapat menumbuhkembangkan dirinya secara optimal. ${ }^{35}$

\section{Dorongan Kemandirian}

Salah satu aspek penting dalam kecakapan ABK adalah kemandirian dalam hidup. Proses pendidikan yang dijalankan berupaya untuk membentuk personal yang mandiri terutama berhubungan dengan tugas hidup sehari-hari. Kemampuan makan, membersihkan tempat, memakai pakaian, contohnya, menjadi salah satu aspek yang dikembangkan. Hal ini mendorong Sekolah Khusus Spectrum untuk mewujudkan siswa ABK yang mampu mandiri dalam tugas hidup sederhana sehari-hari sesuai dengan kemampuan yang dimiliki.

Proses pendidikan yang dijalankan tidak mengarah pada pencapaian teoritis materi belaka. Yang paling ditekankan adalah praktik hidup. Karena hal ini menjadi kemampuan yang menopang ABK untuk dapat menjalani kehidupannya kelak. Kemandirian dalam hal ini tidak hanya berlaku untuk anak normal. ABK pun harus dikembangkan untuk dapat hidup mandiri melalui latihan-latihan dan pengulangan kinerja.

\section{DAFTAR PUSTAKA}

Taufik Abdullah, Metodologi Penelitian Agama (Yogyakarta: PT. Tiara Wacana, 1989), 93.

Koentjaraningrat, Beberapa Pokok Antropologi Sosial (Jakarta: Dian Rakyat, 1985), 56.

Imam Suprayogo, Metodologi Penelitian Sosial Agama (Bandung: Remaja Rosda Karya, 2001), 41.

Andy Dermawan, dkk. Eds, Metodologi Ilmu Dakwah (Yogyakarta: LSFI, 2002), 127.

Marzuki, ,Pembinaan Karakter Siswa melalui Pendidikan Agama Islame, Jurnal Kependidikan, Vol. 41, No. 1, (Mei 2011), 45.

Abdurrahman, Pendidikan Luar Biasa Umum (Jakarta: Dtjen Dikti, 1994), 16. Sardiman AM, Interaksi dan Motivasi Belajar Mengajar (Jakarta: Rajawali Press, 2000), 118.

Al- Syaibani, Falafah Pendidikan Islam (Jakarta: Bintang, 1979), 159.

${ }^{35}$ Ende Supriyadi, Pendidikan Humanistik dalam Islam (Jakarta: STAINU, 2011), 45. 
Internalisasi Nilai Pendidikan Islam dan 'Habit Information' pada Anak Berkebutuhan Khusus di Tangerang Selatan

Salamet, Karakter Peserta Didik dalam Perspektif Pendidikan Islam', Jurnal Pelopor Pendidikan, Vol. 3, No. 1 (Januari 2012), 33.

American Psychiatric Association, Diagnostic and Statistical Manual of Mental Disorder (Washington DC: APA, 2000), 92.

American Psychiatric Association, Diagnostic and Statistical Manual of Mental Disorder (Washington DC: APA, 2000), 93.

World Health Organization, The ICD-10 Classification of Mental and Behavioral Disorder (Genewa: WHO, 1992), 232.

Gerald C. Davison, Abnormal Psychology (New York: John Wiley and Sons, 1998), 436-437.

Muhamad Athiyah Al-Abrasy, Dasar-Dasar Pokok Pendidikan Islam, Terj. Bustomi A. Ghoni dan Jauhar Bahri (Jakarta: Bulan Bintang, 1970), 108.

Tim Penyusun, Kamus Besar Bahasa Indonesia (Jakarta: Balai Pustaka, 1999), 321.

Mudzakir Ali, Ilmu Pendidikan Islam (Semarang: PKPI 2 Universitas Wahid Hasyim, 2009), 148.

Muhammad Qutb, Sistem Pendidikan Islam, terj. Salman Harun (Bandung: PT. Al-Ma'arif, tth), 26.

Muhaimin, Abdul Mujib, Pemikiran Pendidikan Islam, Kajian Filosofik dan Kerangka Dasar Operasionalnya (Bandung: Trigenda Karya, 1993), 241.

Herry Noer Aly, Ilmu Pendidikan Islam (Jakarta: PT. Logos Wacana Ilmu, 1999), 180.

Hasil observasi dan wawancara pada tanggal 19 Nopember, 2016.

Heris Gunawan, Filsafat Pendidikan Islam (Jakarta: Ditjen Pendidikan Islam, 2010), 285.

Raharjo, Pemikiran Pendidikan Islam, Kajian Tokoh Klasik dan Kontemporer (Semarang: Fakultas Tarbiyah IAIN Wali Songo bekerjasama dengan Pustaka Pelajar, 1999), 66.

Hasil wawancara dengan guru Sekolah Khusus Spectrum tanggal 21 November, 2016.

Hewett dan Frenk D, The Emotionally Child in The Classroom Disorders (USA: Ellyn and Bacon, Inc, 1968), 9.

Hasil oservasi pada tanggal 19 dan 20 Nopember, 2016.

Skinner, B. F, Contingencies of Reinforcement (CT: Appleton, 1971), 100. 
Wari Setiawan

Frank Goble, Madzhab Ketiga Psikologi Humanistik Abraham Maslow (Yogyakarta: Kanisius, 1987), 120.

Ende Supriyadi, Pendidikan Humanistik dalam Islam (Jakarta: STAINU, 2011), 45. 